\title{
Geo-disasters induced by the recent earthquakes in Japan and Indonesia
}

\author{
Masakatsu Miyajima ${ }^{1, *}$, Yuko Serikawa ${ }^{2}$, and Hendra Setiawan ${ }^{3}$ \\ ${ }^{1}$ Kanazawa University, Department of Geosciences and Civil Engineering, Kanazawa 920-1192 Japan \\ ${ }^{2}$ Kanazawa University, Graduate School of Environmental Design, Kanazawa 920-1192 Japan \\ ${ }^{3}$ Tadulako University, Bumi Tadulako Tondo Campus, Palu, Central Sulawesi, 94118 Indonesia
}

\begin{abstract}
This paper is focusing on the geo-disasters induced by the 2018 Hokkaido Iburi-tobu earthquake in Japan and the 2018 Sulawesi earthquake in Indonesia. The Hokkaido Iburi-tobu earthquake occurred at east of Iburi region in Hokkaido, Japan on September 6th, 2018. Tremendous number of landslides occurred in the mountain areas at Iburi region. Uplift and sinking of road and inclination of houses were caused by liquefaction in the south eastern part of Sapporo city. The Sulawesi earthquake happened at Central Sulawesi Province, Indonesia on September 28th 2018. The ground displacement triggered by the fault movement caused damage to roads and houses. The large scale ground flows induced by liquefaction occurred in some different sites. This paper reviews the damage induced by the geo-disasters and considers the lessoned learnt from the damaging earthquakes happened in 2018.
\end{abstract}

\section{Introduction}

Many damaging earthquakes have occurred in the world in every year. Especially, many of them occurred in south eastern Asia. The damaging earthquake caused severe geo-disasters in Japan and Indonesia in 2018. This paper is focusing on the geo-disasters induced by the 2018 Sulawesi earthquake in Indonesia and the 2018 Hokkaido Iburi-tobu earthquake in Japan. Surface faulting caused some damage to infrastructures such as road, houses, etc. in Indonesia. Severe liquefaction caused enormous amount of damaged houses in Japan and Indonesia. Large scale ground flows occurred and many persons were killed in Indonesia. This paper reviews the damage induced by the geo-disasters and considers the lessoned learnt from the damaging earthquakes happened in 2018.

\footnotetext{
* Corresponding author: miyajima@se.kanazawa-u.ac.jp
} 


\section{The Hokkaido Iburi-tobu Earthquake in Japan}

\subsection{Outline of earthquake and damage}

An earthquake of about $35 \mathrm{~km}$ in depth and magnitude $M_{J M A}=6.7$ occurred at east of Iburi region in Hokkaido at 3:07 local time on September 6th, 2018. A maximum seismic intensity of 7 was observed at Atsuma town [1]. The human damage of this earthquake were 41 deaths, 18 seriously injured and 731 minor injured. There were 409 completely destroyed, 1,262 partially destroyed and 8,463 slightly damaged houses. 2,249 nonresidential buildings were also damaged. The main cause of these damages was landslides occurred at Atsuma town near the epicenter. Uplift and sinking of road and inclination of houses were caused by liquefaction in the southeastern part of Sapporo city. Enormous liquefaction induced damage occurred in a wide area of Satozuka and Utsukushigaoka towns in Kiyota ward, Sapporo city. Furthermore, all power plants in Hokkaido stopped emergency just after the event, and a massive power outage of 2.95 million households occurred. The blackout was completely eliminated was October 4th. Water supply was also stopped at Sapporo city and some towns. Water stop continued at Atsuma town more than one month.

\subsection{Landslide}

Tremendous number of landslides occurred in the mountain areas at Iburi region. Fig. 1 shows a landslide occurred in Atsuma town. This photograph also shows the damage to Tomisato purification plant of drinking water supply caused by landslide. The total area of landslides was about $13.4 \mathrm{~km}^{2}$ according to the Ministry of Land, Infrastructure and Transport, Japan. This scale is biggest in Japan from 1868. One of causes of the landslides seems to be a large amount of water contained in soil because heavy rain fallen in the previous day of the event by a strong typhoon. It is considered that the descent pumice layer deposited in this area is highly permeable, and clay is formed by chemical weathering, therefore, landslide is likely to occur easily.

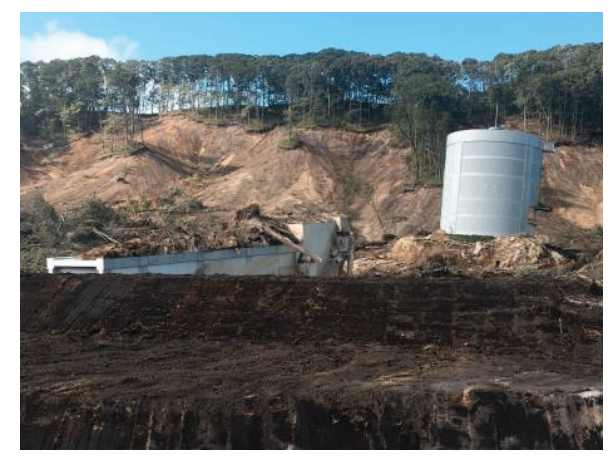

Fig. 1. Landslide at Atsuma town

\subsection{Liquefaction}

Uplift and sinking of road and inclination of houses were caused by liquefaction in the southeastern part of Sapporo city, where hilly land consisting of pyroclastic flow sediment of Shikotsu volcano. Severe liquefaction damage occurred in a wide area of Satozuka and 


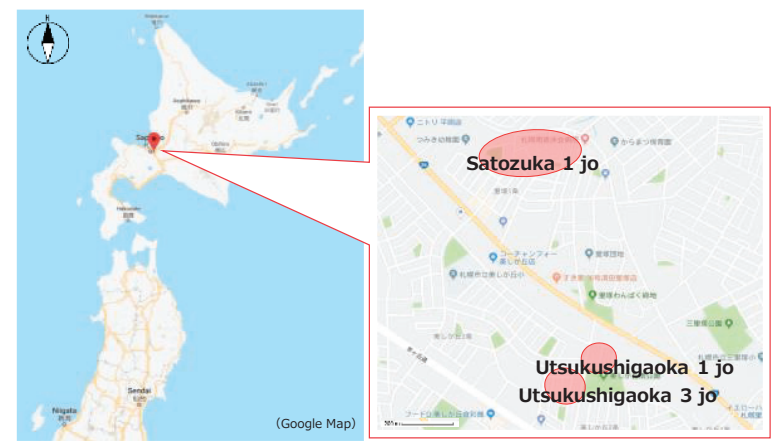

Fig. 2. Location of liquefied sites in Sapporo city

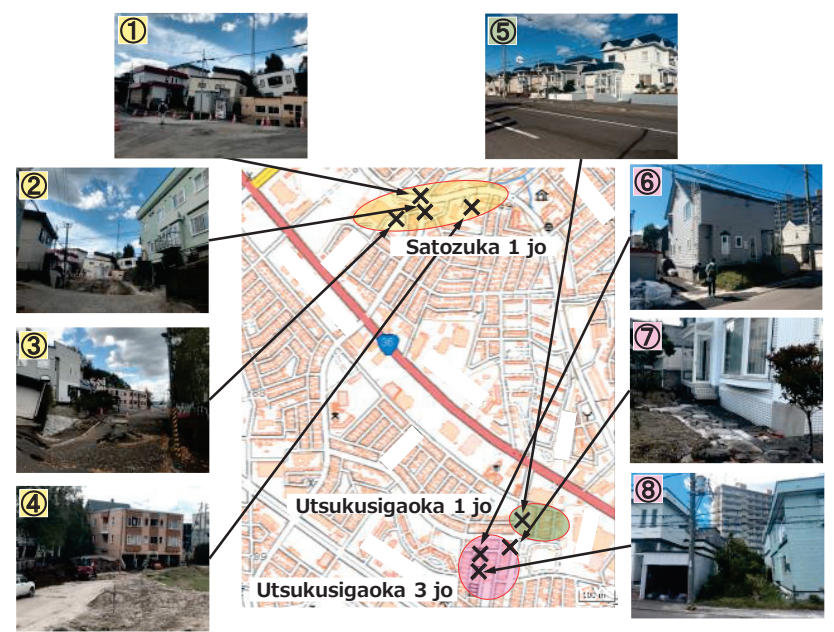

Fig. 3. Damage to housed induced by liquefaction

Utsukushigaoka towns in Kiyota ward, Sapporo city. Fig. 2 shows the location of Satozuka and Ustukushigaoka towns. Some photographs of the damage at each site are shown in Fig. 3. The ground deformation due to liquefaction was the largest and the ground was raised up to about $2 \mathrm{~m}$ in Satozuka 1jo town shown as yellow portion in Fig. 3. Photo. (1) in Fig. 3 shows settlement of the ground and inclination of the houses are remarkable and a puddle of water appeared in front of the house. The road shown in photo. (2) collapsed, and the traffic of the vehicle was difficult. Since the ground level before the earthquake was at the top of this utility hole in photo. (3), it is considered that this road subsided about 1 to $2 \mathrm{~m}$. The inclination of the surrounding houses was large. Photo. (4) shows accumulated sand in height of about $50 \mathrm{~cm}$. It is thought that a large amount of liquefied sand ejected at the sites of photos (1) to (3) was accumulated at the location of photo. (4) because the location of photo. (4) is lower than the sites of photos (1) to (3).

The green portion in Fig. 3 indicates Utsukushigaoka 1jo town. There were many inclined houses due to liquefaction. The houses shown in photo. (5) seems to suffer no damage at first glance, but inclination of houses has occurred. Most of residents have continued to live in the inclined houses just after the earthquake, but many residents moved without being able to withstand the inclination of houses after around one month. 
The red portion in Fig. 3 indicates Utsukushigaoka 3jo town. Many houses caused inclination by liquefaction. The inclination of the house shown in photo. (6) was the second largest inclination in Utsukushigaoka town. The residents of this house had moved soon after the earthquake. The surrounding ground of the house shown in photo. (7) subsided, and a gap between the stairs and the ground was caused. The houses shown in Photo. (8) were inclined to the direction of each house. The right house was with the largest inclination in the Utsukushigaoka town. The utility pole shown in this photograph has settled about $1 \mathrm{~m}$.

Fig. 4 shows inclination of the outer wall of the houses in Utsukushigaoka 1 jo and 3 jo towns. The inclination was shown in color-coded of every $0.25^{\circ}$ on the map. Vector synthesis was performed in two orthogonal directions with larger inclination and the direction of inclination is indicated by an arrow in this figure. If the maximum inclination and the synthesized inclination are less than $0.25^{\circ}$, vector synthesis is not performed and only the direction of the maximum inclination is shown in this figure. The location of the largest subsidence of road is also indicated by red $X$ in this figure. This figure suggests that the houses that were greatly inclined were adjacent and that such houses are inclined in the same direction. Also, the houses were inclined in the direction of the largest subsided road. The number of houses in each inclination angle is shown in Fig. 5. Health problems may occur at the houses with an inclination of $0.6^{\circ}$ or more, and about $53 \%$ of the surveyed houses exceeded this value.

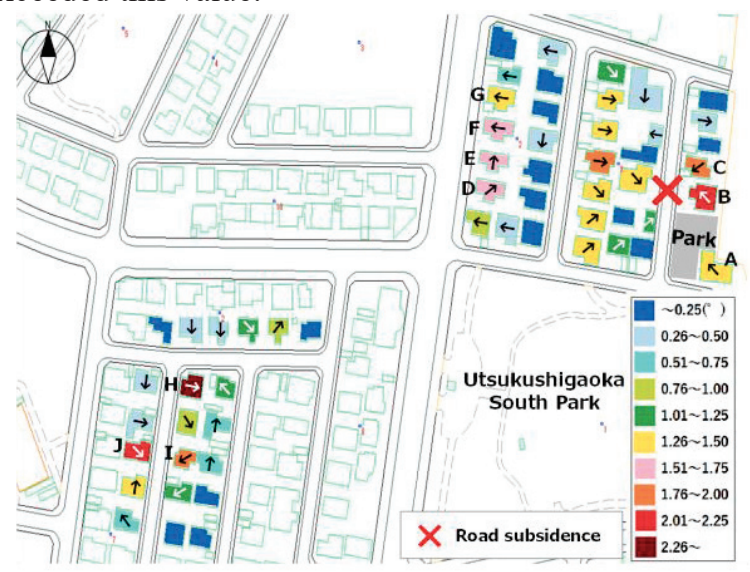

Fig. 4. Inclination of houses and its direction at Utsukushigaoka

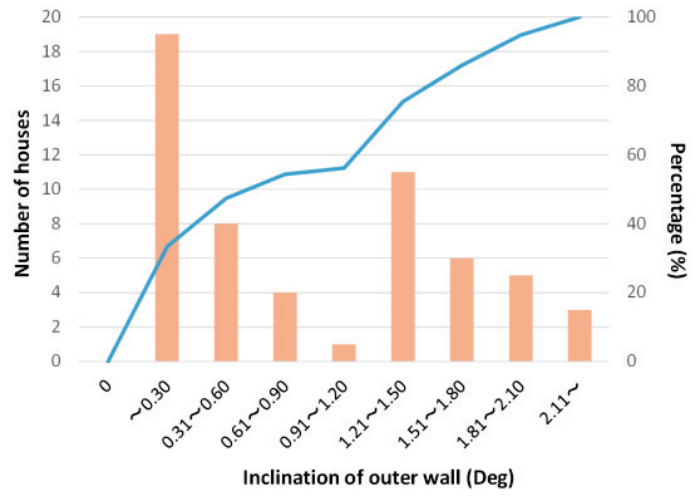

Fig. 5. Number of houses in each degree of inclination 
Fig. 6 is superimposed the past terrain [3] on Fig. 4. According to this figure, the houses built at a former valley are inclined. It can be seen that the houses of $\mathrm{A}, \mathrm{B}$ and $\mathrm{C}$ with large inclination and largely settled road were located at the former valley. The houses of $\mathrm{D}$ and $\mathrm{E}$ were inclined in the direction of north and the houses of $\mathrm{F}$ and $\mathrm{G}$ in the west direction. These areas were formerly flood or valley plain. The houses of H, I and J are also located at the former valley. It is clear that the direction of inclination of the houses coincides with the direction of former valley or flood plain. The surveyed areas of this study was originally recessed areas that erodes mountains, plateaus and terrace, then the area was reclaimed for residential houses. The houses of D, E, F and G were located at the former flood and valley plains, houses $\mathrm{A}$ to $\mathrm{C}$ and $\mathrm{H}$ to $\mathrm{J}$ were located at the former bottom of valley plains. It was revealed that the inclination of houses due to liquefaction is greatly affected by the old topography.

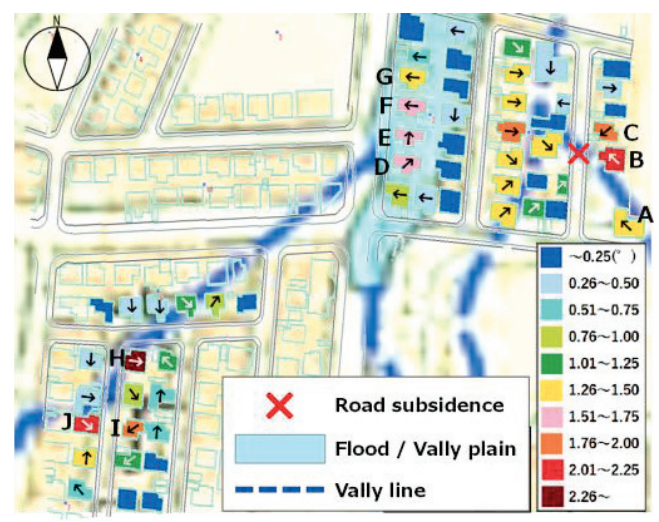

Fig. 6. Inclination of houses and the past terrain

\section{The Sulawesi Earthquake in Indonesia}

\subsection{Outline of earthquake and damage}

On September $28^{\text {th }}, 2018$, at 18:02 local time (10:02 UTC), a strong earthquake of magnitude $M w=7.5$ struck Central Sulawesi Province, Indonesia. Fig. 7 shows the location of the epicenter. The epicenter was located at around $77 \mathrm{~km}$ from Palu city and $20 \mathrm{~km}$ in depth. This event was preceded by several foreshocks, the largest recorded as $M w=6.1$ and occurred at 14:59 local time (06:59 UTC), three hours earlier of that day. Fig. 7 also shows MMI estimated by USGS [4]. According to this figure, MMI=IX is estimated at Palu city and higher intensity is along the fault line (See Fig. 9). The casualties were approximately 2,256 persons, more than 1,000 persons missing, and around 10,000 persons injured in three most affected regions which are Palu city, Donggala and Sigi villages.

\subsection{Surface faulting}

Large ground displacement was found in some particular areas, such as Kedondong, Pipa Air, Pangeran Diponegoro and Cemara streets in Palu city. Fig. 8 indicates the locations of the large ground displacement found in Palu city. These large ground displacements agree with the fault movement of left lateral slip. Fig. 9 shows the fault line at surface estimated by USGS [4]. The legend of this figure indicates estimated amount of slip of fault itself. 
The epicenters of aftershocks were also indicated in this figure. According to this figure, the locations of large ground displacements appeared at surface coincide well with the estimated fault line. Therefore, the large ground displacements seem to be induced by the fault movement.

The ground displacement triggered by the fault movement appeared in Pangeran Diponegoro, Cemara, Kedondong and Pipa Air, streets. The horizontal displacement of the four roads are $2.7 \mathrm{~m}$ of Pangeran Diponegoro street, $3.8 \mathrm{~m}$ of Cemara street, $4.5 \mathrm{~m}$ of Kedondong street and 5.0m of Pipa Air street, respectively. These displacements make roads bent.

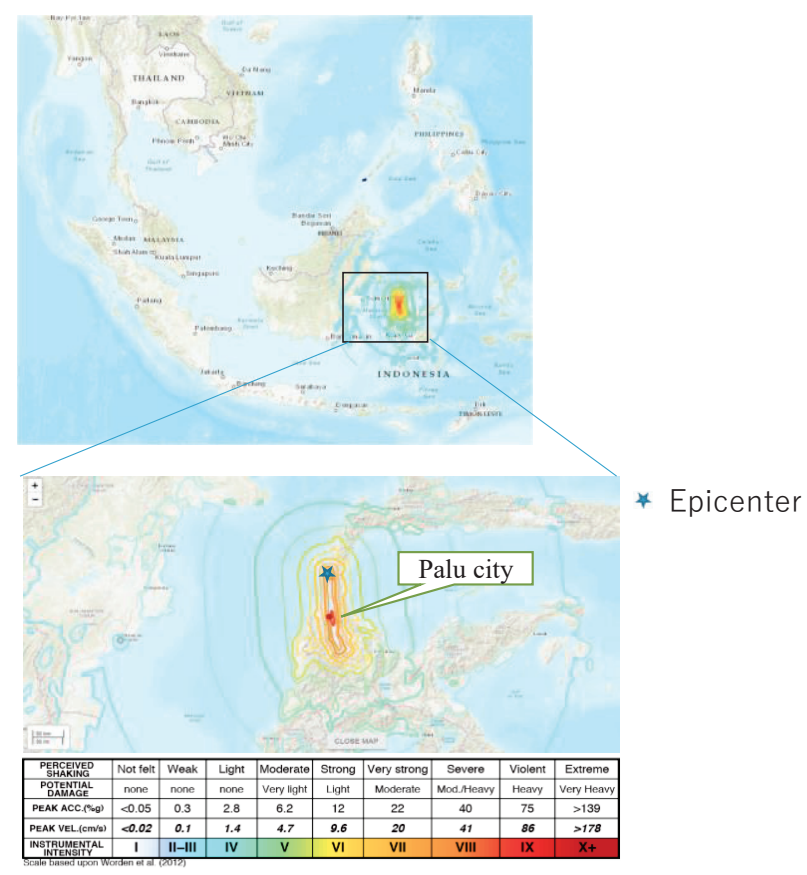

Fig. 7. Location of epicenter and MMI estimated by USGS [4]

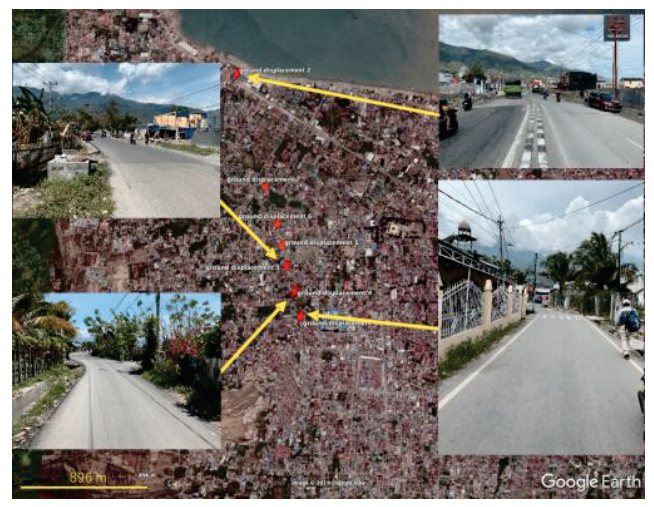

Fig. 8. Location of ground displacement induced by fault movement in Palu city 


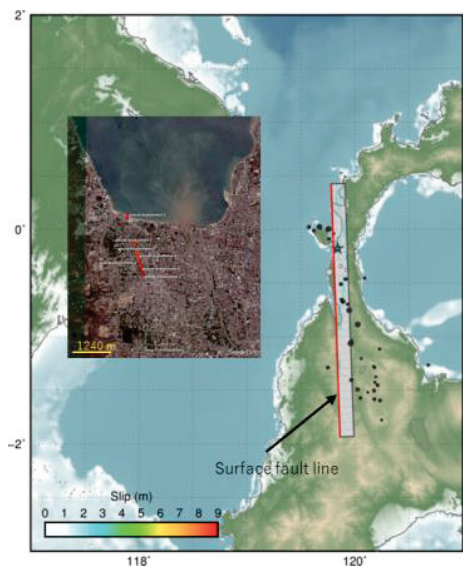

Fig. 9. Fault line at surface estimated by USGS [4]

\subsection{Large ground flow by liquefaction}

The earthquake triggered large-scale ground flow in some different sites, such as Balaroa and Petobo districts in Palu city and Jono Oge and Sibalaya Villages. The locations large ground flow of Balaroa and Petobo districts in Palu city and Jono Oge village and the direction of the ground flow are illustrated in Fig.10 by using Google Earth. Table 1 lists the areas and average slope before the earthquake of each site of large ground flow estimated by using a function of Google Earth. A satellite photo of Sibalaya village after the earthquake cannot obtained, so the area of large ground flow cannot be estimated. Average ground slope of Sibalaya village before the earthquake is about 3.1\%. The ground slope before the earthquake was not so large. The cause of this phenomena was reported as soil liquefaction in the local media. The mechanism should be clarified by using many geotechnical data in near future.

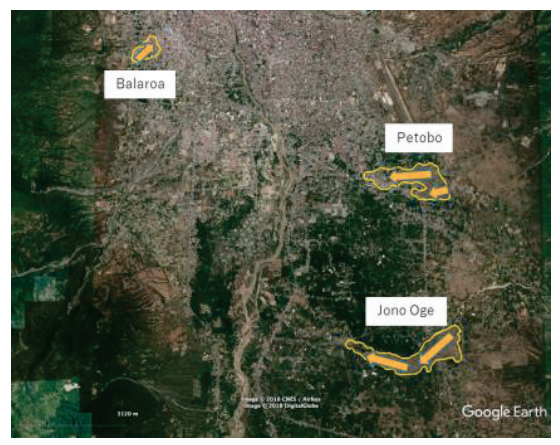

Fig. 10. Location of large ground flows in Palu city

Table 1. Areas and average slope before the earthquake of each site of large ground flow

\begin{tabular}{l|c|c}
\hline Site & Area of ground flow $\left(\mathrm{m}^{2}\right)$ & Average slope $(\%)$ \\
\hline Balaroa & 380,000 & 3.8 \\
Petobo & $1,500,000$ & 2.1 \\
\hline Jono Oge & $1,800,000$ & 1.9 \\
\hline
\end{tabular}


Fig. 11 shows a satellite photograph by Google Earth and some photographs of damage in Balaroa district in Palu city. The direction of the large ground flow is shown by a yellow arrow in this figure. The ground flow occurred from south-west to north-east. Large ground settlements and large tension cracks appeared at the upper side of the flow and collapsed houses were piled up and many houses were buried in the flowed soil at the lower side. Balaroa district is a densely populated area. 600 people were died of the more than 2,000 inhabitants, while more are still missing. The area affected in Balaroa district was around $380,000 \mathrm{~m}^{2}$. Balaroa housing complex almost disappeared due to the ground flow. It is reported that around 1,700 houses were buried due to lateral ground movement.

Fig. 12 shows a satellite photograph by Google Earth and some photographs of damage in Petobo district in Palu city. The direction of the large scale ground flow is also shown by a yellow arrow in this figure. The ground flow occurred from east to west here. Similar to Balaroa district, more than 700 houses were severely destroyed caused by the ground flow and hundreds of people died here. The area affected in Petobo district was much larger than Balaroa, which is around $150,000 \mathrm{~m}^{2}$.

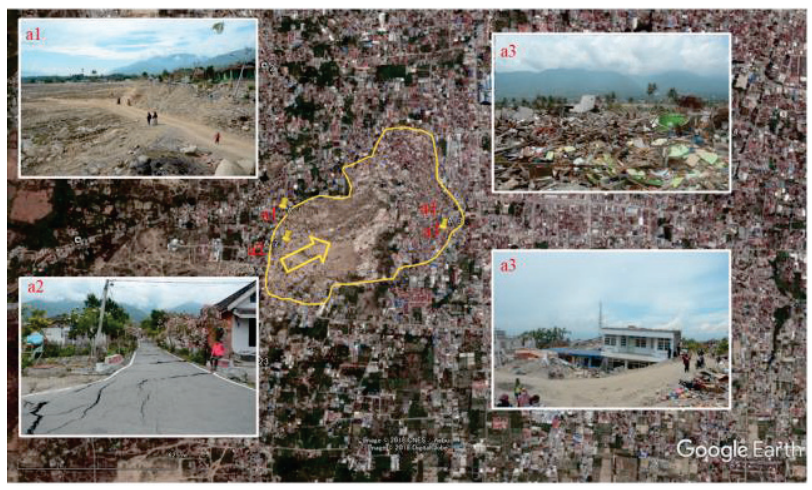

Fig. 11. Satellite photo by Google Earth and some photos of damage at Balaroa district in Palu city

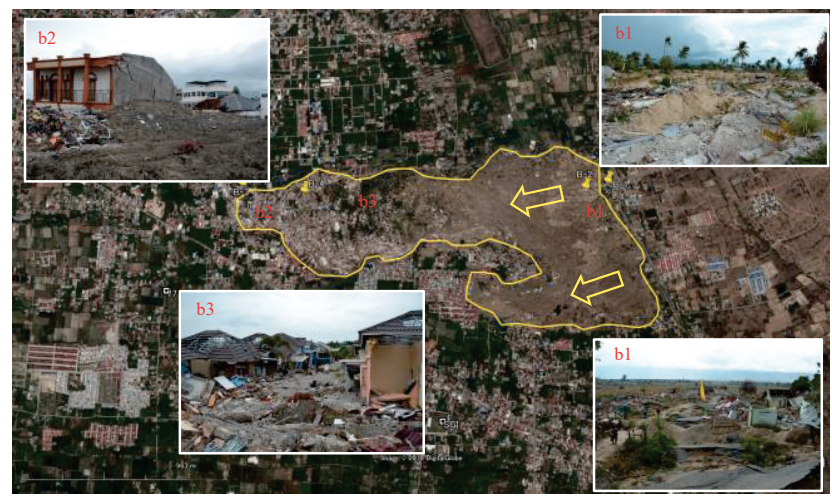

Fig. 12. Satellite photo by Google Earth and some photos of damage at Petobo district in Palu city 
Fig. 13 shows a satellite photograph by Google Earth and some photographs of damage in Jono Oge village. The direction of the large scale ground flow is also shown by a yellow arrow in this figure. The ground flow occurred from east to west. Lateral ground flow occurred as well with the affected area around $180,000 \mathrm{~m} 2$ in Jono Oge village. In this area, at least 34 high school students who joined a bible camp were killed, but it is suspected that many others are dead.

Fig. 14 shows a satellite photograph by Google Earth and some photographs of damage in Sibalaya village. The direction of the large scale ground flow is also shown by a yellow arrow in this figure. Sibalaya village is located around $40 \mathrm{~km}$ south of Palu city. A satellite photograph of Sibalaya village after the earthquake cannot obtained yet. In this area, only three people were dead due to building collapse. However, the severe large ground flow also occurred. The road and houses moved laterally up to about 350 meters shown in Fig. 15. What made this phenomenon extraordinary is that the moving road and some houses only experienced minor damage. The mechanism of the large ground flow should be clarified in near future.

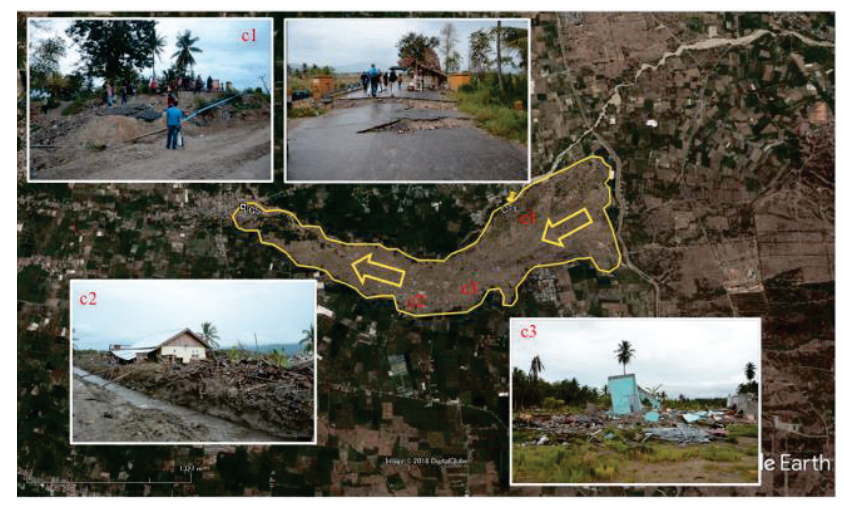

Fig. 13. Satellite photo by Google Earth and some photos of damage at Jono Oge village

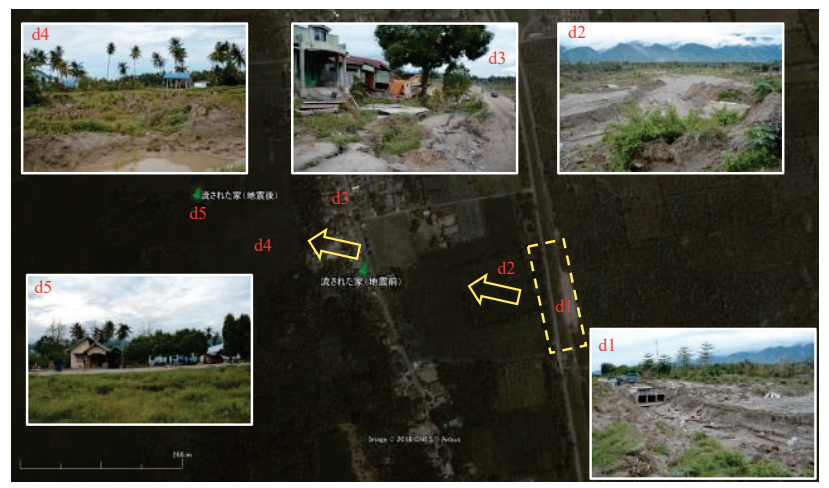

Fig. 14. Satellite photo by Google Earth and some photos of damage at Sibalaya village 


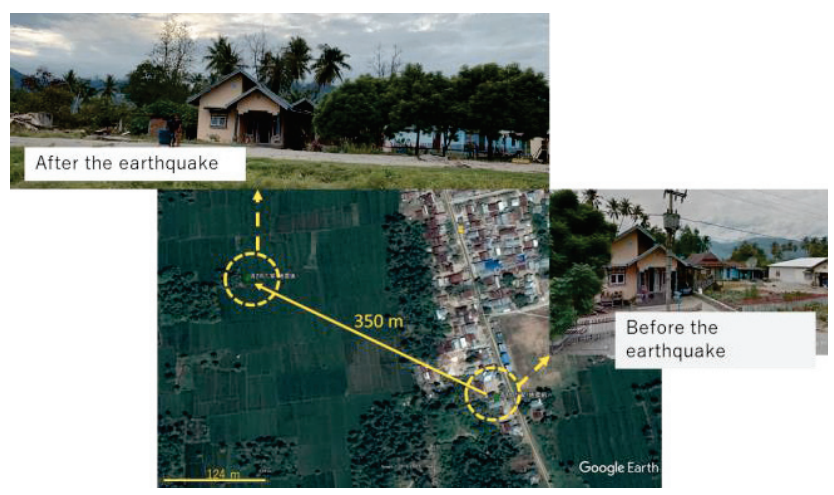

Fig. 15. Horizontal movement of houses and road in Sibalaya village

\section{Conclusions}

This paper reviews the damage induced by the geo-disasters occurred in Japan and Indonesia in 2018. The 2018 Hokkaido Iburi-tobu earthquake caused tremendous number of landslides occurred in the mountain areas at Iburi region. Uplift and sinking of road and inclination of houses were caused by liquefaction in the south eastern part of Sapporo city. Severe liquefaction damage occurred in a wide area of Satozuka and Utsukushigaoka towns in Kiyota ward, Sapporo city. The inclination of 57 houses at Utsukushigaoka town was measured, and the maximum value and inclination direction were shown on the map. The houses located at the reclaimed land of the former river and former valley plain were inclined. Therefore, it is clarified that the old terrain is greatly affected to the inclination of houses. The 2018 Sulawesi earthquake caused large ground displacements and large scale ground flows. The large ground displacement was found in some particular areas in Palu city. The locations of large ground displacements appeared at surface coincide well with the estimated fault line. Therefore, the large ground displacements seem to be induced by the fault movement. The earthquake also triggered large-scale ground flows in some different sites, such as Balaroa and Petobo districts in Palu city and Jono Oge and Sibalaya Villages. The ground slope before the earthquake was not so large. However, affected areas were so large and the distance of flow was large. Therefore, the large ground flow caused severe damage to not only human but also houses and buildings. The mechanism of the large ground flow should be clarified in near future.

\section{References}

1. Japan Meteorological Agency, Report of the2018 Hokkaido Iburi-tobu earthquake Ver.6 , https://www.jma.go.jp/jma/press/1809/07c/kaisetsu201809071600.pdf (last visit: 26 Nov. 2018)

2. Geographical Survey Institute, The old topographical map of Kiyota ward, Sapporo city in 1961, http://www.gsi.go.jp/common/000205584.pdf (last visit: 26 Nov. 2018)

3. Geotechnical Society, Damage induced by the 2018 Hokkaido Iburi-tobu earthquake, https://www.jiban.or.jp/wpcontent/uploads/2018/10/nishimura_watabe_20181002.pdf, pp70-71. (last visit: 10 Mar. 2019)

4. USGS, M7.5 - 70km N of Palu, Indonesia, https://earthquake.usgs.gov/earthquakes/eventpage/us1000h3p4/executive. (last visit: 10 Mar. 2019) 